\title{
(32) \\ Assessment of Heavy Metals in Water Contaminated with Petroleum Products in Keffi Local Government Area, Nasarawa State, Nigeria.
}

Makpo, J.K., Ameh, S.M., Asarya, A. and Gambo, Y.P.

Department of Zoology, Faculty of Natural and Applied Sciences, Nasarawa State University Keffi, Nigeria.

Corresponding Author:Jamesmakpo4truth@gmail.com

\begin{abstract}
This work assessed the presence of heavy metals in water contaminated with petroleum products in Keffi Local Government Area. Two water sampling station were selected based on the stratified method of sampling of Antau River. Station A is located along Federal Government College Keffi popularly known as Antau Bridge where Agricultural and mechanical activities, with sales of petroleum product take place. Station B was located at Dadin Kowa known as Gada manu where human activities such as bathing and washing takes place which served as control. The distance between stations is $1 \mathrm{~km}$. The procedural plan of this study was monthly sampling of water from both Stations. Materials such as funnel, sampling container, distilled water, conical flask, filter paper, $50 \mathrm{ml}$ polypropylene centrifuge tube, cooler were used. Heavy metal concentration were determined using $X$ - ray Fluorescent Spectroscopy (XRF) at the Center for Energy Research and Training (CERT), Ahmadu Bello University Zaria. The water parameters of the four samples were determined using the Extech instrument. The result on Physico - chemical parameters revealed the values obtained from contaminated water samples to be $\mathrm{pH}$ (7.31), Dissolved Oxygen (1.14), Electrical Conductivity (8.22), Total Dissolved Solid (4.13), Temperature (27.45) and Salinity (0.091) while the controlled Station at point B were pH (7.43), DO (7.35), EC (3.14), TDS (1.54), Temperature (26.75), Salinity (0.094) respectively. From the result obtained, the heavy metal contaminated samples had the following values: $\mathrm{Mg}(29.31 \pm), \mathrm{Al}(218.69 \pm), \mathrm{Si}(230.12 \pm), \mathrm{S}(1153.65 \pm), \mathrm{Cl}(54.25 \pm), \mathrm{Ca}(106.56 \pm)$, $\mathrm{Ti}(23.66 \pm), \mathrm{Cr}(3.15 \pm), \mathrm{Fe}(15.92 \pm), \mathrm{Cd}(7.54 \pm)$. For the control sample at point $\mathrm{B}$, the following values

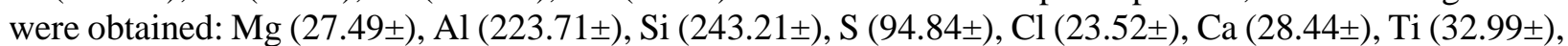
$\mathrm{Fe}(16.63 \pm), \mathrm{Cd}(7.67 \pm)$ respectively. The P-value was $0.8105(\mathrm{p}>0.05)$ for the water quality parameters while for the concentration of heavy metal P-value was $0.2054(\mathrm{p}>0.05)$. This implies that there was no significant difference between the concentrations of elements. However, the concentration values of heavy metals in the contaminated water at Station A and control water samples at Station B were higher than the World Health Organization values (Standard) for drinking water
\end{abstract}

Keywords: Heavy Metals, Contaminated Water, Petroleum Products, Keffi 


\section{Introduction}

The term heavy metal has been called a "misinterpretation", in an IUPAC technical report due to the contradictory definition and its lack of a coherent scientific basis. Concentration of these metals in soil is an indicator of environmental pollution (Hajara et al., 2010). The heavy metals can react with various contents of aquatic environment and can associate with various geochemical phases in the sediments Morillo, et al. (2004).

Among aquatic biota, freshwater mussels are desirable organisms for bio monitoring purposes (Viarengo et al 2007) since these organisms are in direct contact with polluted parts of water and sediments of their habitats can accumulate high levels of heavy metals in soft parts of their bodies (Farris \& Van Hassel, (2007). Freshwater mussels are sensitive indicators of chemical pollution due to their filtration activity (Atkinson, \& Vaughn, 2015. Chowdhury et al., (2016). In freshwater mussel, mantle and gills have respiratory and feeding functions (Bril. 2014) and significant potential for accumulation of heavy metals and other pollutants (Chakraborty, 2010 and Kolarevic et al.,2016).

In recent years, there has been an increasing ecological and global public health concern associated with environmental contamination by these metals. The impact of pollution in the vicinity of overcrowded cities and from industrial effluents and automobiles has reached a disturbing magnitude and is arousing public awareness (Begum et al., 2009). Excessive levels of pollution are causing a lot of damage to human and animal health, plants including tropical rain forests as well as the wider environment (Khan and Ghouri, 2011).

The accumulation of heavy metals in our environment has intensified in recent years due to population growth, industrialization and new technological developments. This phenomenon is of great concern because heavy metals constitute considerable hazards to human health due to their toxicities, accumulative tendencies and persistence in the environment (Ayenimo et al., 2005). Occurrence of potential toxicants in the aquatic ecosystem causes a reduction in the quality of the aquatic environment that results in impaired level of dissolved oxygen (DO), $\mathrm{pH}$, temperature, biological oxygen demand, and chemical oxygen demand (Roberts et al., 2001). Organisms in aquatic environments are usually exposed to a complex mixture of chemicals causing multiple damages at the organisms, population and ecosystem level, in organ function (Ginebreda et al., 2014).

Different compounds in polluted water are reported to damage the genetic material of exposed organisms and therefore cause genotoxic effects. The toxicity of these elements is due to their ability to cause, oxidative damage to living tissues (Bakar et al., 2007). The degeneration and malformation (morphological alterations) of the cells reflect one aspect of the cytotoxic impacts after exposure to pollutants and serve as an index of cytotoxicity (Harabawy et al., 2014). Metals were of particular concern due to their toxicity.

\section{Materials and Method Study Area}

This study was carried out at Antau River located in Keffi Metropolis, the headquarters of Keffi Local Government Area of Nasarawa State, Nigeria. Keffi is about $58 \mathrm{Km}$ from Abuja (the Federal Capital Territory) and $128 \mathrm{Km}$ from Lafia, Nasarawa State Capital. The town is situated on latitude 80 5" North and longitude 70 50" East and about 850 meters above the sea level (www.wikipedia). Keffi has population of 92,664 (NPC 2006), making it the second populated city in Nasarawa State. It has a total land mass of $27,117 \mathrm{Km}^{2}$ (Akwa et al., 2008).

\section{Materials Used}

Materials used include Funnel, sample containers, distilled water, conical flask, filter paper, $50 \mathrm{ml}$ polypropylene centrifuge tube, cooler was used in this study where the cases best contributing to the information needs of the study will be selected. Two different water bodies within Keffi town were selected for sampling. Point A close to source of petroleum product contamination served as Station A while the other not situated near any petroleum 
product contamination source which served as control was Station B.

\section{Machine used}

$>\quad \mathrm{XRF}$ (x-ray fluorescence spectroscopy)

\section{Sample collection and treatment}

Two water sampling station were selected based on the stratified method of sampling of Antau River. Station A is located along Federal Government College Keffi popularly known as Antau Bridge where Agricultural and mechanical activities, with sales of petroleum product take place. Station B was located at Dadin Kowa known as Gada Manu where a human activity such as bathing and washing takes place. Water samples were collected from the control source Station B into a 1ltr pre cleaned polyethylene sample containers prior to the sampling and the contaminated water source with petroleum product at Station A. The sample bottles where thoroughly rinsed with the sample to be collected 1ltr of each sample was divided into two portions. The first portion was used for Physico-chemical analysis according to standard procedures described by (APHA, 2005).

The second portion was passed through a $0.45 \mu \mathrm{m}$ pore size filter paper to remove extraneous materials according to (Yeskis \& Zavala 2002). An initial portion of the filtrate was used to rinse $100 \mathrm{ml}$ conical flask used to collect the sample filtrate. The sample filtrate was then stabilized or acidified with $2 \mathrm{ml}$ nitric acid to prevent bacterial activities and adsorption of heavy metal to the container wall. Each pretreated sample was taken in to a $50 \mathrm{ml}$ polypropylene centrifuge tube and stored in a freezer $4^{\circ} \mathrm{C}$. Heavy metal concentrations were determined using an X-ray Fluorescence spectroscopy (XRF) at the Centre for Energy Research and Training (CERT) Ahmadu Bello University, Zaria. The instrument settings and operational conditions were in accordance with the manufacturer's specifications. The instrument was also calibrated with analytical grade standard metal solutions.

\section{Statistical Analysis}

The concentration of the elements for contaminated and uncontaminated water was subjected to statistical analysis using SPSS statistical software (version 17. 0). Mean and standard deviation of the concentration of the elements across samples was computed and analysis of variance (ANOVA) was carried out to test for the significant difference in concentration of the elements between contaminated and uncontaminated water. The correlation between the concentrations of elements was also obtained. The results were presented in tables.

\section{Results}

Table1 represents Physico - Chemical parameters of the contaminated (Station A) and control (Station B) water. Various parameters were determined such as Dissolved Oxygen (DO), pH, Salinity, Electrical Conductivity (EC), Temperature and Total Dissolved Solid (TDS). The water contaminated with petroleum product has lower DO $(1.14 \pm 0.21)$ than the control $(7.35 \pm 0.21)$; this is due to the water contaminated with the products. Petroleum products reduce the amount of DO in water. Occurrence of potential toxicants in aquatic ecosystem causes a reduction in the quality of the aquatic environment that results in impaired level of Dissolved Oxygen (DO), $\mathrm{pH}$, temperature, biological oxygen demand, and chemical oxygen demand. The temperature $\left({ }^{\circ} \mathrm{C}\right)$, Total Dissolved Solid and Electrical Conductivity $(\mathrm{mg} / \mathrm{L})$ were both higher in contaminated water than in the control water. This may be due to the high level of contaminant which makes the water unfit for the habitation of some aquatic dwelling organism. Dissolved Oxygen and $\mathrm{pH}$ are higher in control sample than in contaminated water which makes the water fit for habitation and less pollution. Salinity is also higher in control but not too significant. 
Table 1: Physico - Chemical Parameters of Contaminated and Control Water

\begin{tabular}{lcc}
\hline Parameters & Station A & Station B \\
\hline & Mean \pm SD & Mean \pm SD \\
\hline Dissolved Oxygen $(\mathrm{mg} / \mathrm{l})$ & $1.14 \pm 0.21$ & $7.35 \pm 0.21$ \\
$\mathrm{pH}\left(\mathrm{H}_{2} \mathrm{O}\right)$ & $7.31 \pm 0.12$ & $7.43 \pm 0.33$ \\
Electrical Conductivity $(\mathrm{S} / \mathrm{m})$ & $8.22 \pm 0.20$ & $3.14 \pm 1.21$ \\
Total Dissolved Solid $(\mathrm{mg} / \mathrm{l})$ & $4.13 \pm 1.10$ & $1.54 \pm 0.02$ \\
Temperature $\left({ }^{\circ} \mathrm{C}\right)$ & $27.45 \pm 0.32$ & $26.75 \pm 0.05$ \\
Salinity $(\mathrm{PPT})$ & $0.091 \pm 0.01$ & $0.094 \pm 0.0030$ \\
\hline
\end{tabular}

Table2. Heavy metal in both Station A and B water samples with petroleum product includes; Magnesium (Mg) 29.1 and 27.49, Aluminum (Al) 0.92 and 3.47, Silicon (Si) 9.16 and 1.78, Phosphorus (P) 0.00 and 0.00, Sulphur (S) 1.81 and 1.30, Chlorine $(\mathrm{Cl}) 2.20$ and 1.31 , Calcium $(\mathrm{Ca})$ 6.41 and 0.42 , Titanium (Ti) 0.89 and 5.73, Cadmium $(\mathrm{Cd}) 0.02$ and 0.61 , Tin $(\mathrm{Sn}) 0.00$ and 0.00 , Barium (Ba) 0.00 and 0.00 , Mercury $(\mathrm{Hg})$ 0.00 and 0.00 , Lead $(\mathrm{Pb}) 0.00$ and 0.00 , Vanadium (v) 0.00 and 0.00, Manganese ( Mn) 0.00 and 0.00, Cobalt (Co) 0.00 and 0.00 , Nickel (Ni) 0.00 and 0.00 , Cupper $(\mathrm{Cu}) 0.00$ and 0.00 , Zinc $(\mathrm{Zn}) 0.00$ and 0.00 , Bromine $(\mathrm{Br}) 0.00$ and 0.00 and Iron $(\mathrm{Fe})$ 1.67 and 0.09 Table 2 shows the mean and standard deviation of the concentration of the elements for both Station $\mathrm{A}$ and $\mathrm{B}$ water. $\mathrm{Sn}, \mathrm{Ba}, \mathrm{Hg}, \mathrm{Pb}, \mathrm{V}, \mathrm{Mn}$, $\mathrm{Co}, \mathrm{Ni}, \mathrm{Cu}, \mathrm{Zn}$ and; $\mathrm{Br}$ were not significant (less than $0.000 \mathrm{mg} / \mathrm{kg}$ ) at both Station A and B. Cr was detected in Station A but was not present in Station B. While Cd was observed in Station A and Station $\mathrm{B}$ water samples. $\mathrm{Mg}, \mathrm{S}, \mathrm{Cl}, \mathrm{Ca}$, and $\mathrm{Ti}$ were relatively higher in contaminated (Station $\mathrm{A}$ ) water sample compared to control sample (Station B) While $\mathrm{Al}, \mathrm{Si}, \mathrm{Fe}$, and $\mathrm{Cd}$ were relatively higher in control (Station B) water sample.

Table 2: The Concentration $(\mathrm{mg} / \mathrm{kg})$ of Elements in the Contaminated and Control Water Sample

\begin{tabular}{|c|c|c|}
\hline & Station A & Station B \\
\hline Element & Mean \pm SD & Mean \pm SD \\
\hline $\mathrm{Mg}$ & $29.31 * * \pm 29.31$ & $27.49 * * \pm 27.49$ \\
\hline $\mathrm{Al}$ & $218.69 * * \pm 0.92$ & $223.71 * * \pm 3.47$ \\
\hline $\mathrm{Si}$ & $230.12 * * \pm 9.16$ & $243.21 * * \pm 1.78$ \\
\hline $\mathrm{P}$ & $0.00 * \pm 0.00$ & $0.00 * \pm 0.00$ \\
\hline $\mathrm{S}$ & $113.65^{* *} \pm 1.81$ & $94.84 * * \pm 1.30$ \\
\hline $\mathrm{Cl}$ & $54.25^{* *} \pm 2.20$ & $23.52 * * \pm 1.31$ \\
\hline $\mathrm{Ca}$ & $106.56^{* *} \pm 6.41$ & $28.44 * * \pm 0.42$ \\
\hline $\mathrm{Ti}$ & $33.66^{* *} \pm 0.89$ & $32.99 * * \pm 5.73$ \\
\hline $\mathrm{V}$ & $0.00 * \pm 0.00$ & $0.00 * \pm 0.00$ \\
\hline $\mathrm{Cr}$ & $3.15 * * \pm 3.15$ & $0.00 * \pm 0.00$ \\
\hline $\mathrm{Mn}$ & $0.00 * \pm 0.00$ & $0.00 * \pm 0.00$ \\
\hline $\mathrm{Fe}$ & $16.63^{* *} \pm 1.67$ & $15.97^{* *} \pm 0.09$ \\
\hline Co & $0.00 * \pm 0.00$ & $0.00 * \pm 0.00$ \\
\hline $\mathrm{Ni}$ & $0.00 * \pm 0.00$ & $0.00 * \pm 0.00$ \\
\hline $\mathrm{Cu}$ & $0.00 * \pm 0.00$ & $0.00 * \pm 0.00$ \\
\hline $\mathrm{Zn}$ & $0.00 * \pm 0.00$ & $0.00 * \pm 0.00$ \\
\hline $\mathrm{Br}$ & $0.00 * \pm 0.00$ & $0.00 * \pm 0.00$ \\
\hline Mo & $0.00 * \pm 0.00$ & $0.00 * \pm 0.00$ \\
\hline $\mathrm{Cd}$ & $7.54 * * \pm 0.02$ & $7.57 * * \pm 0.61$ \\
\hline $\mathrm{Sn}$ & $0.00 * \pm 0.00$ & $0.00 * \pm 0.00$ \\
\hline $\mathrm{Ba}$ & $0.00 * \pm 0.00$ & $0.00 * \pm 0.00$ \\
\hline $\mathrm{Hg}$ & $0.00 * \pm 0.00$ & $0.00 * \pm 0.00$ \\
\hline $\mathrm{Pb}$ & $0.00 * \pm 0.00$ & $0.00 * \pm 0.00$ \\
\hline
\end{tabular}

* Concentration of elements not significant

** Concentration of elements significant at 0.05 level 
250.000 Mg Al Si P S Cl Ca Ti Cr Fe Cd Concentration (mg/kg) Elements Control Vs Contaminated

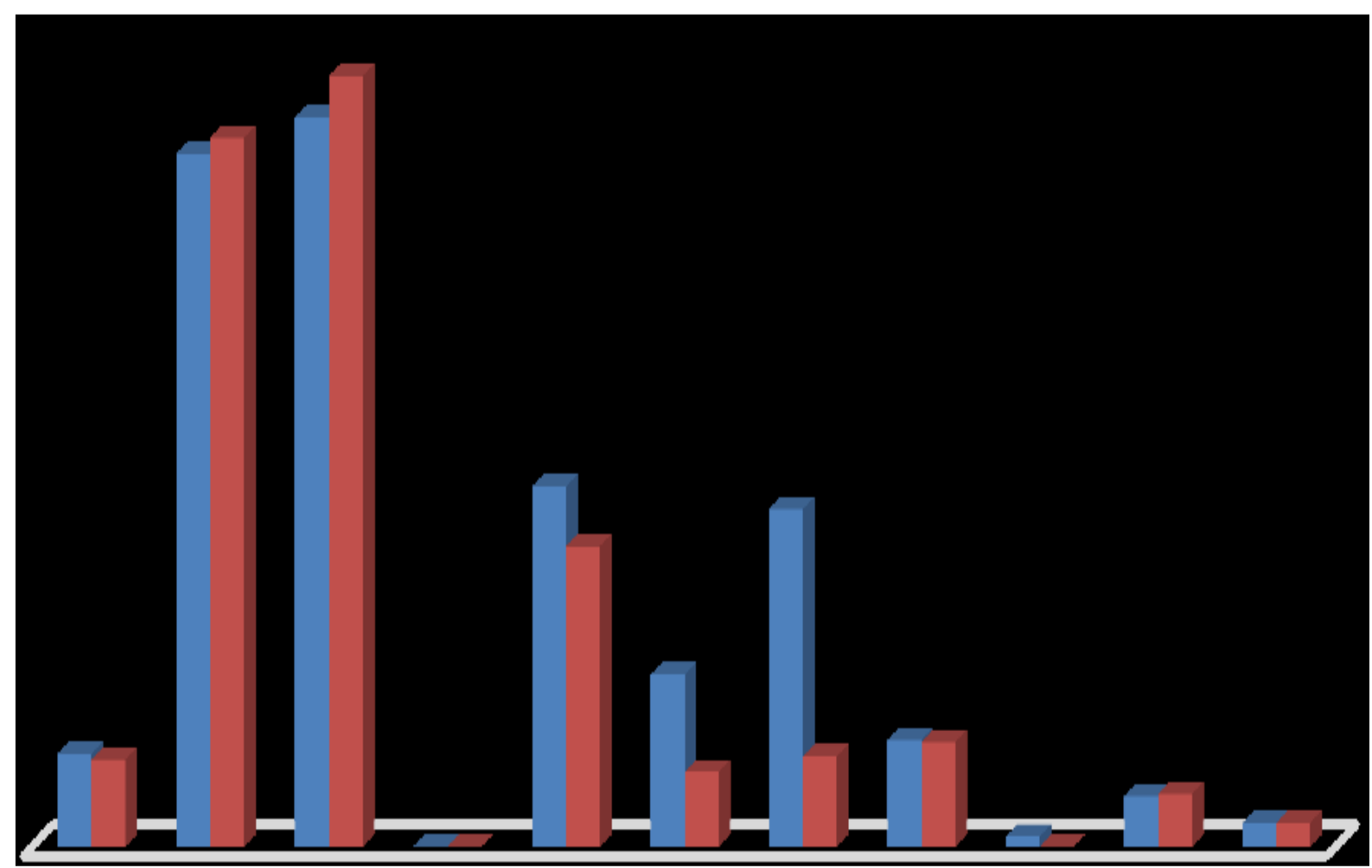

Figure 1: Concentration of elements in contaminated and control water samples 0.00050 .000100 .000 $150.000200 .000250 .000 \mathrm{Mg} \mathrm{Al} \mathrm{Si} \mathrm{P} \mathrm{S} \mathrm{Cl} \mathrm{Ca} \mathrm{Ti} \mathrm{Cr} \mathrm{Fe} \mathrm{Cd} \mathrm{Concentration} \mathrm{(mg/kg)} \mathrm{Elements} \mathrm{Control} \mathrm{(Station}$ $\mathrm{B}$ and Contaminated (Station A) water samples.

Table 3 shows the correlation of heavy metals in contaminated and non-contaminated water. There is a strong positive correlation existing between $\mathrm{Al} / \mathrm{Si}, \mathrm{Al} / \mathrm{Fe}, \mathrm{S} / \mathrm{Cl}, \mathrm{S} / \mathrm{Ca}$, $\mathrm{S} / \mathrm{Cr}, \mathrm{S} / \mathrm{Mo}, \mathrm{Ca} / \mathrm{Cr}, \mathrm{Cl} / \mathrm{Ca}, \mathrm{Ti} / \mathrm{Fe}$ and $\mathrm{Cr} / \mathrm{Mo}$ and a strong negative correlation between $\mathrm{Mg} / \mathrm{Al}, \mathrm{Mg} / \mathrm{Ti}, \mathrm{Mg} / \mathrm{Cr}, \mathrm{Mg} / \mathrm{Fe}, \mathrm{Al} / \mathrm{Ca}, \mathrm{Al} / \mathrm{Cl}$,
$\mathrm{Al} / \mathrm{S} \mathrm{S} / \mathrm{Ca}$, and $\mathrm{S} / \mathrm{Cl}$ from the results obtained. Both the contaminated water sample and the control sample were highly polluted above the WHO standard 2018 making it unfit for consumption and subsequently for other living organisms that inhabit the water.

Table 3: Correlation between Elements in contaminated and control water samples

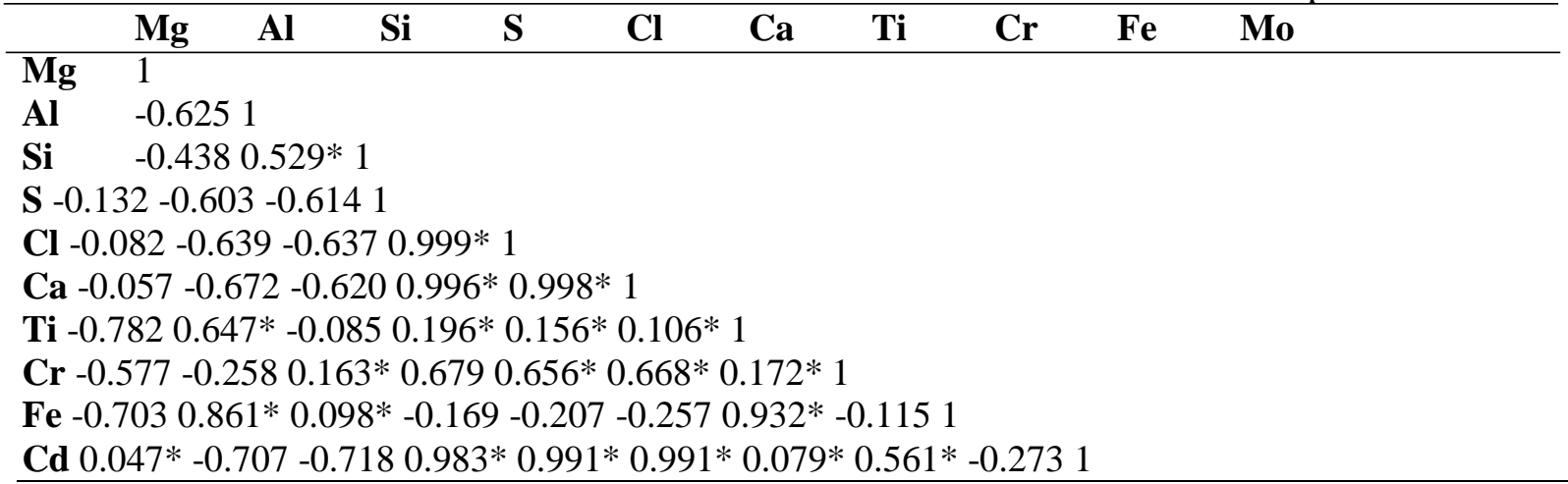

Elements whose concentration are lower than $0.000(\mathrm{mg} / \mathrm{kg})$ are not included in the correlation matrix

* Positive correlation 


\section{Discussions \\ Physico - Chemical Parameters}

The chemical character of any water determines its quality utilization (Elueze et al., 2004). The quality is a function of the physical, chemical and biological parameters to which it could have been subjected to a particular use it is intended for (Tijani, 1994). The temperature range observed $\left(27.45^{\circ}, 26.75^{\circ}\right)$ were slightly lower than the values observed by (Oni, 2000) who reported a temperature range $\left(28\right.$ to $30^{\circ} \mathrm{C}$ and 27 to $30^{\circ} \mathrm{C}$ ) of contaminated water at Ibadan and this is also very close to the values observed by (Olayinka, 1999) who observed a temperature range of 26.7 and $29.10^{\circ}$ in shallow underground water. The $\mathrm{pH}$ and electrical conductivity observed were (7.31), (8.23) respectively. This is in contrast with the values observed by (Ahmed et al., 2016). Who observed a value of $\mathrm{pH}$ (8.33), and electrical conductivity (381.30)

\section{Concentration of Heavy Metals}

This concentration of heavy metals as stated in table 2 above is in agreement with the result of (Ahmed et al., 2016) which showed a high level in the concentration of $\mathrm{Al}$ and $\mathrm{Fe}$ at Station B which was above the WHO permissible limit. This could be as a result of the use of pesticides and fertilizers which are composed of $\mathrm{Al}$ and Fe. The heavy metal with the least concentration was $\mathrm{Cr}$ while that with the highest concentration was $\mathrm{Si}$ in contaminated (Station A) water sample. The heavy metal with the least concentration in non-concentrated water sample was $\mathrm{Cd}$, the heavy metal with the highest concentration was $\mathrm{Si}$.

\section{Correlation between Elements in contaminated (Station A) and control (Station B) water samples}

The positive correlation between $\mathrm{Al}$ and $\mathrm{Si}$ is in contrast with the result of (Hajara et al., 2015). Heavy metals are diffuse and conservative pollutants that bio-accumulate and bio-magnify along the food chain with deleterious effects on the aquatic ecosystems and subsequently humans that depend on the aquatic organism as sources of food. Although cadmium, iron, calcium and chromium are vital in metabolic processes, efforts should be made to ensure that they and other heavy metals do not exceed the prescribed world Health Organization (WHO) and Federal Environmental Protection Agency (FEPA) acceptable limits. All environmental policy should be enhanced and campaigns carried out to educate the public on the importance to protect and preserve aquatic systems and their resident biota. Biological removal of heavy metals in water can be used, in Phytoremediation, plants play a great role in the biological process as they break down, reduce, degrade and remove these contaminants using various parts, such as the root, leaves, stomata, cell wall and the shoot (USEPA, 2000; Rajendran et al., 2003; Sharmae et al., 2012). In microbial remediation, microbial communities are of primary importance. The process is cost effective process, with non-hazardous end products (Ahmed et al., 2004). According to Gupta et al., (2000) and Duffus et al., (2002), the major groups of microorganisms that have been implicated in heavy metal remediation are bacteria (such as Anthrobacter, Bacillus sp, Citrobacter, Cupriavidus metallidurans, 37 Cyanobacteria, Enterbacter cloacae, Alcaligenes, Sphinganonas, Rhdococcus, Mycobacterium and Arthrobacter) and fungi (such as Aspergillus tereus, Penicillium chrysogeum, Candida and Rhodotorula mucilaginosa). Beside bacteria and fungi, certain protozoa, such as Euplotes mutabilis and algae, such as Oscillatoria sp, Chlorella vulgaris and Chlamydomonas sp have been reported to possess metal reducing capabilities (Ramasamy et al., 2006).

\section{Conclusion}

This study examined the presence and concentration of heavy metals in the water from mechanic and agricultural activities and the control samples in Keffi, Nasarawa state. It was discovered that water affected by petroleum product had a lower level of dissolved oxygen, $\mathrm{pH}$ and salinity. All other parameters were higher in the control sample. For the control samples Dissolved Oxygen, $\mathrm{pH}$, Salinity was 
higher and all other parameters were lower. For the concentration of heavy metals, Water affected by petroleum product had higher values of $\mathrm{Mg}, \mathrm{S}, \mathrm{Cl}, \mathrm{Ca}$, $\mathrm{Ti}$ and $\mathrm{Cr}$ all other elements were lower. For the control sample $\mathrm{Al}, \mathrm{Si}, \mathrm{Fe}$ and $\mathrm{Cd}$ were higher all other elements were lower in the control sample. This will pose a serious health risk to the inhabitants of the area. All aquatic animals are affected. It can also result to neurodegenerative disorder, nervous system, kidney and cancer diseases. Even the fishes in the River can be affected which indirectly affects man through the food chain.

\section{References}

Ahmed, T. I., Ekbal, T. W., and Mariana, S. A. (2016). Heavy Metals Assessment in Water, Sediments and Some Organs of Oreochromis niloticus under the Impact of Sewage Water. Journal of Heavy Metal Toxicity and Disease Journal 1(1):4-10

Ahmed, M, Marshall, W. F., Husseiny, A. A., Rao, R. M. \& Goktepe, I. (2004). The use of nutshell carbons in drinking water filters for removal of trace metals. Journal of Water Research. 38(4):1064-1068.

Akwa, V. L., Bimbol, N. L., Samaila, K. L. \& Marcus, N. D. (2008). Geographical perspective of Nasarawa State. Onaivi Printing \& publishing Company, Keffi. $\operatorname{Pg} 3$.

Atkinson, C. L. \& Vaughn, C. C (2015.) "Biogeochemical hotspots: Temporal and spatial scaling of the impact of freshwater mussels on ecosystem function," Freshwater Biology, vol. 60, no. 3, pp. 563-574.

Ayenimo, J.G., Adeeyinwo, C.E., and Amoo, I.A, (2003). Heavy Metal Pollutants in Warri, Nigeria. Kragujevac Journal of Science Vol. 27.

Bakar, A., Semin, R., and Ismail, A.R, (2007). The internal combustion engine diversification technology and fuel research for the future: A Review. Proceeding of AEESEAP, Kuala Lumpur, Malaysia pp $57-62$.
Begum, A., Hariskrishna, S., and Irfanulla, K., (2009). Analysis of heavy metals in water sediments and fish samples of Madivala Lakes of Bangolore, Karnataka. International Journal of Chemical Technology; Research 1(2)

Bril, J. S., Durst, J. J., Hurley, B. M., Just, C. L. \& Newton, T. J. (2014). "Sensor data as a measure of native freshwater mussel impact on nitrate formation and food digestion in continuous-flow mesocosms," Freshwater Science, vol. 33, no. 2, pp. 417-424,

Chakraborty, S., Ray, M. \& Ray, S. (2010). "Toxicity of sodium arsenite in the gill of an economically important mollusc of India," Fish and Shellfish Immunology, vol. 29, no. 1, pp. 136148.

Chowdhury, G. W., Zieritz, A. \& Aldridge, D. C. (2016). "Ecosystem engineering by mussels supports biodiversity and water clarity in a heavily polluted lake in Dhaka, Bangladesh," Freshwater Science, vol. 35, no. 1, pp. 188-199.

Duffus, J. H. (2002). Heavy Metals-A Meaningless Term. Pure and Applied Chemistry 74:793807.

Elueze, A.A., and Ntor, M.E, (2004). Organic Geo - chemical Appraisal of limestone and shales in part of Eastern Dahomey Basin, Southwestern Nigeria, Journal of Mining and Geology. 40, 29 - 40.

Fournier, M., Pellerin, J., Clermont, Y., Morin, Y. \& Brousseau, P. (2001) "Effects of in vivo exposure of Mya arenaria to organic and inorganic mercury on phagocytic activity of hemocytes," Toxicology, vol. 161, no. 3, pp. 201-211.

Farris, J. L. \& Van Hassel, J. H. (2007). Freshwater Bivalve Ecotoxicology, CRC Press, New York, NY, USA,

Ginebreda, A., Kuzmanovic, M., and Guasch, H, (2014). Assessment of multi - chemical pollution using toxic units: Compound prioritization, mixture characterization and relationship with biological descriptions. Science of the total environment 468, 469 pp $715-723$. 
Gosling, E. (2003). Bivalve Molluscs: Biology, Ecology and Culture, Blackwell, New York, NY, USA,

Gupta, R., Ahuja, P., Khan, S., Saxena, R. K. \& Mohapatra, H. (2000). Microbial bioasorbents: groundwater in a coastal aquifer of Andhra Pradesh, India. Environmental Earth Sciences, 66(8), 2143-2169.doi:10.1007/s12665-0111438-5

Hawabury, A.S and Mosleh, Y, (2014). The role of vitamin A, C, E and Selenium as antioxidants against genetoxicity and cytotoxin of Calcium, Copper, Lead and Zinc on erythrocytes of Nile tilapia, Oreochromis niloticus. Ecotoxicolology and environmental. Serf. 104: 28 - 34.an, M.A and Ghouri, A.M, (2011). Environmental pollution: Its effect on life and its remedies. International Resesrch Journal. Vol. 11

Kolarevic, S., Kracun-Kolarevic, M., Kostic J. et al., (2016). "Assessment of the genotoxic potential along the Danube River by application of the comet assay on haemocytes of freshwater mussels: the joint Danube Survey 3," Science of the Total Environment, vol. 540, pp. 377-385.

Morillo, J., Usero, J. \& Gracia, I. (2004) "Heavy metal distribution in marine sediments from the southwest coast of
Spain," Chemosphere, vol. 55, no. 3, pp. 431-4412.

Eisler, R., (1986) “Zinc hazards to fish, wildlife and invertebrates: a synoptic review," US Fish Wildlife Service Reproductive Biology, vol. 85, pp 1-6. Pandey, S. Parvez, S., Sayeed, I., Haque, R., Bin-Hafeez, B and Raisuddin, S, (2003) "Biomarkers of oxidative stress: a comparative study of river Yamuna fish Wallago attu (B1. \& Schn.)," Science of the Total Environment, vol. 309, no. 13, pp. 105-115.

Ramasamy, S., Wang, H., Quach, H.N, and Sampath, K, (2006). Zebrafish, staufen 1 ans staufen 2 are required for the survival and migration of primordial germ cells. Journal of Developmental Biology 292 (2): 393 - 406.

Rejendran, P., Muthukrishnan, J and Ganasekran, P, (2003). Microbes in heavy metal remediation. Indian Journal of experimental biology 41 (9): $935-944$.

Viarengo,A., Lowe,D., Bolognesi,C., Fabbri, E. \& Koehler, A. (2007). "The use of biomarkers in bio-monitoring: a 2-tier approach assessing the level of pollutant-induced stress syndrome in sentinel organisms," Comparative Biochkemistry and Physiology, vol. 146, no. 3, pp. 281-300. 